\title{
Research on School Sports for the Cultivation and Development of College Students' Ideological and Political Education
}

\author{
Juhua Song \\ Department of Physical Education \\ Nanjing University of Information Science \& Technology \\ Nanjing, China 210044
}

\begin{abstract}
School sports is an important means to carry out patriotism, collectivism and socialist education for contemporary college students and it is a necessary starting point for ideological and political education of contemporary college students. According to the training objectives of sports and the direction of education reform, in combination with the requirements of social development for talents in the new period, this paper analyzes the relationship between college sports and ideological and moral education of college students, and makes discussion of the cultivation of students' comprehensive quality and the ideological and cultural quality education in physical education.
\end{abstract}

Keywords-school sports; ideological and moral; quality education

\section{INTRODUCTION}

In schools, physical education and ideological and political education are integrated in the talent training, both existing in the overall structure of education, and they are interconnected and interpenetrated. In the Physical education, the ideological and political education and skills teaching and physical exercise, physical fitness enhancement are internal unitive and interactive. The ideological and political education provides guarantee for the completion of sports skills teaching and the enhancement of physical quality; vice versa, in the teaching of sports knowledge and Sports skills, students may strengthen their physical quality but also obtain ideological and political education. From the teaching objective, physical education and ideological education have a relationship of means and purpose, that is, ideological and political education is one of the purposes of physical education, and at the same time, physical education is also one of the means of ideological and political education of students; From the teaching content, physical education and ideological and political education have relationship of carrier, that is, the content of physical education should be one of the carriers of ideological and political education; from the teaching process, physical education and ideological and political education have a relationship of approach, that is, physical education is one of the main ways

Fund Project: Party building research project 2017 of Nanjing University of Information Science \& Technology, project number: 2017nxddj-yb010. of ideological and political education. From above, it can be seen that ideological and political education exists in all aspects of physical education.

\section{THE RELATIONSHIP BETWEEN SCHOOL SPORTS AND IDEOLOGICAL AND POLITICAL EDUCATION}

\section{A. It Helps the Ideological and Political Education to Achieve the Integration of Rational Enlightenment and Emotional Inspiration}

Interest is a form of behavioral motivation, and also a very active drive form with strong emotional color. Sukhomlinskii, educator of the former Soviet Union pointed out: "Learning interest is an important drive power of students to learn," and "the task of teachers is to unremittingly develop students' sincere satisfaction with learning so that students can produce the emotion to hope learning and to establish the state of eager learning ." just when learning meet the needs of students to grow and succeed, can students' interest in learning be easily inspired, and thus students may have the learning motivation. At the same time, when meeting the demand of students in learning, the cultivation of learning interest must be helpful for inspiration of students' feelings of learning. Emotion is an important part of the irrational factors in the spiritual world of human. The most of rational action of human cannot form without people's initiative, enthusiasm, creativity, or without passion and impulse. When a certain object makes students have a strong sense of intimacy and identity, the passion of emotional object will form, and then produce the promotion for their behavior. A lot of successful people can be full of lasting power in their action because of their high emotions. Some scholars pointed out that cognition is necessary for the formation of ideological and moral quality, but the emotional factors has more correlation rate. Only when correct understanding and positive emotions combines together, students can establish a belief in the process of practice, and gradually develop their behavioral habits and build their ideology and morality. In a sense, for the ideological and moral issues, the judgment may be correct only when the sense and sensibility integrate completely. Therefore, when ideological and political education is implemented in the 
sports that are interested by students, the educators of ideological and political education can apply the emotional power of students to achieve the combination of rational enlightenment and emotional inspiration, so as to achieve the work efficiency of "teaching through interest".

\section{B. It Helps Students to Practice the "Combination of Knowledge and Practice"iIn the Process of Sports}

In the implementation of ideological and political education through sports, only when ideological and political educators combine the awareness and behavior training of students, the "internalization" and "externalization" of the ideological and political education can be realized, and further students can build good behavior habit and good ideology and morality. In the cultivation of good moral character, students' correct understanding and positive emotions can only solve the problem of internalization of ideological and political education, but it cannot solve the problem of externalization of ideological and political education. Therefore, in order to make good efficiency of ideological and political education in sports, we must first solve the problems of cognition and emotion, and on this base we pay attention to students' will cultivation and behavior training. The will cultivation and behavior training plays an important role in the "externalization" of ideological and political education. Cognition comes from practice, so the good ideological and moral character of students is cultivated in social practice, and reflected in the words and deeds of students in social practice. the students participated in sports often have great interest in the sports items they attend, and devoted a lot of enthusiasm, so they can consciously strengthen their cognition of noble sports ideas and moral in sports, sublimate their feelings of sports thought and moral, abide by the law and rules of sports, and strive to achieve the conformity of their understanding of sports with their sports behavior. This also makes the ideological and political education combined with students' interest in sports, transfer students' understanding of ideology and morality in sports into the promotion of students' noble sports ideas, and makes students strictly follow the sports law and the relevant ethics and rules, which is also the "externalization" process of ideological and political education. Just in this sense, we can say the combination of ideological and political education with students' interest in sports activities will help students to practice the "combination of knowledge and practice" in their participation in sports.

\section{THE COUNTERMEASURES OF SCHOOL SPORTS IN Cultivation of COllege STUdENTS' IDEOLOGICAL AND POLITICAL EDUCATION}

\section{A. Change the Concept, and Introduce the Ideological and Moral Quality Education into the Classroom Teaching of Physical Education}

The implementation of ideological and moral quality education should starts from the change of concept. First of all, leaders and teachers should have unified understanding and reach consensus. As the backbone of social development, high quality of college students will have an important impact on their personal success and the country's future. It has become an urgent and realistic new topic for schools to cultivate the students in demand of social development and with higher ideological and moral qualities. From the perspective of physical education, both the leaders and the general teachers should not only establish the concept of ideological and moral quality education, but also combine the ideological and moral quality education with physical education in practice and establish a new concept of physical education, both passing the novel and rich sports knowledge to students and introducing purposefully and consciously the ideological and moral quality education activities into the physical education.

\section{B. Improve the Overall Quality of Physical Education Teachers, Create a High-Quality TeacherTeam}

"Teachers are of profound learning and lofty morality". The key to implementation of physical education is to have a high-quality teacher team. First of all, teachers should earnestly practice what they preaches personally, play their exemplary role; have professional ethics, strong sense of responsibility, provide quality service for students; become a model for others, take the lead, teach students by their example as well as verbal instruction; assiduously study professional knowledge, improve cultural quality and professional quality. Second, they should develop rules and regulations, conventions for students, requiring students to maintain environmental health, cherish public property, participate in activities in a civilized way, keep neatly dressed, and keep a civilized and courteous way. Teachers should follow the trend of the times, do will the sports guidance. This requires teachers have forward-looking and infusive thinking, so as to enrich the students' sports knowledge and skills and improve the quality of physical education.

\section{Build a Good Cultural Environment of Sports, Purify the Minds of College Students}

School is a very important place to teach and cultivate students, we should create good cultural environment of sports, organize more sports meeting, sports festivals, sports week and other relevant activities, provide the multi-way, multi-channel and multi-means activities platform, which has a important role for students' quality education. More and more colleges and universities hold the campus sports arts festivals, campus sports meeting and campus sports performances to create a healthy, positive and lively culture atmosphere for campus sports, which makes the form of ideological and political education more flexible, the content richer, and the method more suitable for the real life of college students. In the positive and progressive influence of the campus sports culture, College students get cultivation of sentiment, exercise of will, purification of mind, sublimation of personality, positive change of thinking and behavior styles. 


\section{Pay Attention to the Combination with Teaching Content of Physical Education}

In the teaching of college physical education, different teaching contents are related to the different project, and different projects have different characteristics; we should combination the teaching content of ideological and political education with the specific characteristics of the project, adopt different forms of teaching in the study of different projects, and then students will have different learning experiences in the different forms of teaching, so the ideological and political education must combine with the characteristics of each project. For example, in football teaching and training, students will focus their attention on the training ground, students will conduct a comprehensive observation and mastery of the training situation but also make efforts to find the opponent's weaknesses in order to win the chance. At this time, students will properly transfer their focus of the activities, reduce their thinking and awareness of other problems, and at this time, their some psychological state as well as will and quality that usually are not shown, will be presented subconsciously, then the teacher should find problems and provide the corresponding ideological and political education according to these characteristics of students.

\section{E. Increase the Publicity, and Play the Role of Social Public Opinion on Sports}

Simply, the social public opinion on sports actually refers to the evaluative views and tendentious attitude of a society group on some kind of sports behavior, sports events or sports figures in a certain range of society through the conscious or spontaneous expression, dissemination and exchange of a considerable number of organized or unorganized people from a tradition, experience or belief and desire, etc. As a kind of social activities, the social opinion on sports not only is a kind of attitude expression of praise and criticism on a certain moral behavior of sports in people' judgment of good and evil, but also It is an important way to convey the information of behavior value to the sports behavior parties, can directly or indirectly express the demand of sports agency, sports organization and even the whole nation for sports development, and also can influence the sports behavior parties though the opinion so as to restrict, motivate and promote their work. From these, it can be seen that good public opinion on sports can effectively improve the self-discipline of participants in sports activities and contribute to the benign interaction between sports and ideological and political education. Therefore, we should pay attention to the positive publicity to play the role of social public opinion on sports and to promote the benign interaction between sports and ideological and political education.

\section{CONCLUSION}

In the new period, physical education has the dual effect of tangible and intangible types, and the physical education in colleges plays a subtle role in improving the students' ideological and moral quality. Physical education and ideological and moral quality education is concordant, with a common purpose of education, they are make a mutual promotion and complementation each other. The cultivation of ideological and moral quality is a difficult task of physical education. Therefore, the physical education teachers should make great efforts to unify the thinking and treat the cultivation and improvement of overall quality of students as a systematic project. Only when having a noble ideological and moral quality, solid professional thinking, complete knowledge structure, high degree of intellectual development, comprehensively good physical fitness, can students adapt to the development of modern society. In short, the benign interaction between sports and ideological and political education not only helps to form sports morality and play the role of sports morals, but also can reflect the value of ideological and political education in sports, so as to promote the benign interaction between the two in the new period.

\section{REFERENCES}

[1] Huang Xinjia. Create A Culture Atmosphere of Campus Sports to Enhance the Overall Quality of Students [J]. Sports Science, 2004 (6): 67-71.

[2] Cai Xiaowei, Tian Juntao. Campus Sports Culture and College Students' Ideological and Political Work [J]. Sports World, 2006 (10) 46-48.

[3] Comrade Hu Jintao's Speech on the Conference of Strengthening and Improving Students' Ideological and Political Education [R] .2005$1-18$.

[4] Zhu Ping, Kong Duyun, Yao Benxian. Contemporary College Students' Ideological and Political Education: the Status Quo, Problems and Prospects [J]. Ideological and Political Education Research, 2007 (1): 55-57. 